\title{
Assessment of the Effectiveness of Traditional Media for the Promotion of Tourism in This Digital Age in KwaZulu-Natal South Africa
}

\author{
Elvis Madondo ${ }^{1}$, Douglas Chiguvi $^{2} \&$ Ruramayi Tadu ${ }^{3}$ \\ ${ }^{1}$ Faculty of Management Sciences, Durban University of Technology, P O. Box 1334, Durban 4000, South Africa \\ ${ }^{2}$ Senior Lecturer: Marketing Programmes, Entrepreneurship Department, BA ISAGO University P. Bag 149, Gaborone, \\ Botswana \\ ${ }^{3}$ Vice President - Academic Affairs \& Research, BA ISAGO University, P. Bag 149, Gaborone, Botswana
}

Correspondence: Douglas Chiguvi, Senior Lecturer: Marketing Programmes, Entrepreneurship Department, BA ISAGO University P. Bag 149, Gaborone, Botswana.

Received: March 25, 2019

doi:10.11114/bms.v5i4.4598
Accepted: September 5, $2019 \quad$ Online Published: October 31, 2019

URL: https://doi.org/10.11114/bms.v5i4.4598

\begin{abstract}
This is a study which seeks to measure the effectiveness of traditional media for the promotion of tourism in this digital age in KwaZulu-Natal South Africa. This study employed a descriptive research design and the questionnaire was used to collect the data. The findings revealed that traditional media and online media are more or less equally competitive for the promotion of tourism. Traditional media is still effective for the promotion of tourism in this digital age, most especially in the domestic market. The study concluded and recommended that tourism marketers and authorities need to come to terms with traditional media and online media coexistence. There is no need to rely on one media to do it all. Where traditional media lacks, online media must be there to make up the difference and enhance the tourist's experience.
\end{abstract}

Keywords: traditional media, online media, and tourism marketing

\section{Introduction}

According to Hanekom (2015: 1) tourism is regarded as a critical component on the National Development Plan of South Africa because of its capacity to spur growth across the wider economy and create jobs. There is a need for ongoing efforts to promote the tourism sector for it to remain competitive and continue contributing to the welfare of the people (Nzima 2015: 5). The promotion of tourism is expected to go to great lengths to attract more tourists to visit KwaZulu-Natal (KZN). Durban Tourism (2013: 1) states that although KZN has done well to attract and hold major events in the Durban City, the number of visitors has declined in the last five years. This decline in the volume of tourists has adversely affected employment, financial returns, private sector capital investment and revenue generating opportunities. KZN's Tourism Master Plan Strategic Development calls for more promotion in order to position the province as a top 20 tourism destination in the world by 2020. This is the vision of Tourism KwaZulu-Natal (TKZN) in terms of promoting tourism in the province. Blaga (2013: 31) highlights that the effectiveness of a communication system depends on how the tourism organisations manages to develop the messages, choose the target audience, and select the media (means) by which the information is conveyed to the target audience. It is the means or the media component of the whole communication system which is under investigation in this study.

There is a need for ongoing efforts to promote the tourism industry for it to remain competitive and continue contributing to the welfare of the people. Modern age advertising is divided into two main groups, traditional media and online media advertising. In the past, the tourism industry and other business organisations relied heavily on traditional media to market their products and services (Strategic Direction 2016: 9). However, the advancement of network technologies and the increasing penetration of the Internet have prompted increasing numbers of organisations around the world to use online (Internet) advertising in order to attract more customers in cyberspace, and to enhance their product sales and company profile. Goyal and Sharma (2013: 46) further claim that the advent of online media in tourism business has altogether revolutionised the whole system of performing business and brought about new ways of 
promoting business. In light of these developments, many marketing practitioners fear that traditional media have entered a death spiral and are no longer competitive in doing meaningful business. They believe that traditional media will succumb to technology innovations that revolutionised the promotion industry (Chao et al. 2012: 12). In this contemporary tourism marketing environment, the performance of traditional advertising media and online media needs to be revealed in order to guide media choice decisions by tourism marketers and authorities.

\section{Literature Review}

Statistics South Africa (2016: 3) define tourism as all the activities undertaken by individuals travelling to places away from their usual environment, and staying there for business, study, leisure and other purposes. Van and Tu, (2016) define tourism as a temporary movement of people outside their normal place of residence and work, together with the facilities provided to cater for those visits and the activities undertaken during the stay in those visited places. According to Pomering, Noble and Johnson (2011: 962) promotion is the means by which organisations attempt to remind, persuade and inform customers about destinations, brands or products that they sell.

The tourism sector in KwaZulu-Natal is largely dominated by private organisations and a few public owned organisations such as Leisurenet and Kersaf. The vision of Tourism KwaZulu-Natal is to position the province as the continent's leading tourism destination. This can be achieved through the use of the right media and other promotional strategies (TKZN Strategy 2014: 5). Promoting tourism in this ever-changing world of media is the premise behind this study. Seymour et al. (2009: 19) state that the provincial government of KwaZulu-Natal plays a critically important role in the development and promotion of tourism in the province. The private sector also provides a significant impetus towards the development and promotion of tourism within the province. This private sector bears the risks of investment and a large part of the responsibility for successful development and marketing of tourism.

Advertising is the main element which tourism organisations can use to influence actual and potential tourists to visit various tourist destinations in the province (Durban Tourism 2013: 11). Advertising can be executed in different media types. Modern age advertising is divided into two main groups, traditional media and online media advertising. In the past, the tourism industry and other business organisations relied heavily on traditional media such as newspapers, television, billboards, magazines, and radio, to market their products and services (Strategic Direction 2016: 9). However, the advancement of network technologies and the increasing penetration of the Internet have prompted increasing numbers of organisations around the world to use online (Internet) advertising in order to attract more customers in cyberspace, and to enhance their product sales and company profile (Huang 2012: 9524). Worldwide spending on the Internet promotion forecast to reach $\$ 745$ billion in 2019, an increase of $15.4 \%$ over the $\$ 646$ billion spent in 2018, according to a new update to the International Data Corporation (IDC). IDC expects internet promotion to surpass the $\$ 1$ trillion mark in 2022. Furthermore, Fyall, Fletcher and Spyriadis (2009: 115) claim that tourist destinations and products are better promoted via the Internet than via traditional means such as television, catalogues, and brochures. In this contemporary tourism marketing environment, the performance of traditional advertising media needs to be revealed to tourism marketers since it has shown a decline in its efficacy as compared to online advertising. However, Debasish and Murilidhar (2013: 79) argue that communication tools have merits and demerits which do not affect the effectiveness of a communication system. This background has shown that the advertising media landscape is ever-changing due to technological advancements and more ongoing research is required on this topic, especially in the tourism sector, given its unique nature.

Today, traditional advertising media- television, newspapers, radio, cable TV, and magazines have been massively shaken by the Internet revolution which transformed the environment in which they all operate (Sturgis 2012: 1). In support of this change, Bruhn, Schoenmueller and Schafa (2012: 770) state that the media landscape has undergone immense transformation over the past decade. Social media seem to offer unlimited new marketing opportunities and are increasingly seen as replacing traditional media advertising. This rapid growth of online advertisement has raised the question of whether these developments have diminished the relevance of traditional media in the advertising industry.

According to Chao et al. (2012: 12) the rise of online advertising as one of the most prominent promotion vehicles has prompted business organisations around the world to strategically shift their focus to online media. On the other hand, the Strategic Direction (2016: 9) has observed that even the way people are consuming media has changed in recent years. Bruhn et al. (2012: 771) add that consumers are turning away from traditional media such as radio, TV, or magazines and increasingly utilising social media to search for information. In light of these developments, many marketing practitioners fear that traditional media have entered a death spiral and are no longer competitive in doing meaningful business. To others, promotion through traditional media is already dead and the media will sooner or later disappear completely. They believe that traditional media will succumb to technology innovations that revolutionised the promotion industry (Strategic Direction 2016: 7). They add that traditional media is facing a risk of being forced out 
of the market altogether. There have been many speculations that traditional media will fade away in the near future, and others proclaiming that it has already faded away globally (Chipp and Chakravorty 2016: 374), Strategic Direction (2016: 8), Chao et al. (2012: 21), and Huang (2012: 9525). Therefore, this study seeks to bridge this knowledge gap and to make an original contribution to the collective knowledge base of advertising and the promotion of tourism by revealing contemporary insights on the performance of both traditional advertising media and online media.

\subsection{Digital Revolution}

Online advertising is said to have posed a great challenge to traditional media advertising because of its many advantages and that it provides practitioners an additional vehicle to access potential customers and obtain an instant feedback (Chao et al. 2012: 21). According to Howison, Finger, and Hauschka (2014: 296) Internet technology has disturbed the traditional business models of many industries, including media, finance and retail and this has had great implications in the tourism industry. The Internet has transformed traditional marketing and communication strategies used in the tourism industry. This is supported by Loda (2014: 306) who states that the digital revolution has already changed almost everything about how business is conducted in the tourism industry. Internet emerged as a modern advertising medium. However, this is not to say that traditional media is now obsolete. Seymour et al. (2009: 17) suggest that most domestic visitors to KZN still rely on traditional sources of information. On a contrary, Fyall, Fletcher and Spyriadis (2009: 115) claim that tourist destinations and products are better promoted via the Internet than via traditional means such as television, catalogues, and brochures.

\subsection{Traditional Advertising Media}

Traditional marketing approaches evolve around the concept of "pushing" a promotional message to a broad audience. Customers are directly exposed to messages conveyed through radio, newspaper, and television. According to Dahlen and Edenius (2007: 34) the attitudes of consumers towards advertising are continually becoming more and more negative, resulting from the increase in ad clutter. This increase in ad clutter in traditional advertising media such as newspapers, radio and TV has had negative effects on both the advertising content and the media. It was argued that reactions to the advertised message are more favourable when the ad is placed in non-traditional medium than in traditional medium where consumers can readily identify the advertised message as advertising. According to Zentner (2012: 913) the increases in Internet penetration are negatively correlated with changes in expenditures on advertising on magazines, newspapers, and television. However, all this does not diminish the relevance and effectiveness of traditional media in the promotion industry. Like any online media, traditional media also has its own shortcomings.

\subsection{Effectiveness of Traditional Media}

According to Seymour et al. (2009: 18) the most important reasons for South Africans who considered visiting KwaZulu-Natal as a tourism destination were that they saw an advertisement in the magazine, saw a television commercial aid or red an article about the region. The Omnibus survey noted that $86.6 \%$ of all domestic travels to KwaZulu-Natal did not request any information to make arrangements for their holiday online but obtained information from other traditional sources. The survey revealed that $76.6 \%$ of the respondents indicated that they had seen the KwaZulu-Natal logo before, 35\% on television and 31.4\% on billboards. Loda (2014: 305) indicates that television is acknowledged to be the most powerful advertising medium and it reaches a broad spectrum of present and prospective customers. The greatest benefit of television advertising lies in its ability to reach a larger number of customers at a given time period. This makes cost per contact relatively low in advertising than with other elements of the promotion mix

The advertising industry is rapidly advancing in the digital world, forcing a restructuring in traditional advertising media. Travellers and tourism marketers have widely adopted the use of online media; however, this digital revolution does not diminish the relevance of traditional advertising media in promoting tourism. It simply calls for a restructuring in the advertising industry.

\section{Research Methodology}

This study employed a descriptive research design which aims to achieve the objective of the study. Non-probability sampling techniques were employed in recruiting the participants. Convenience and purposive sampling techniques are the two types of non-probability sampling techniques that were used. In total, 400 questionnaires were distributed and 298 were returned, giving a $74.5 \%$ response rate. Participation was entirely voluntary and the whole process was carried out with great courtesy. Structured questionnaires were used to collect data. The rationale behind the use of a structured questionnaire is to solicit information from the tourists on key issues pertinent to this study. Cronbach's alpha, KMO and Bartlett test were conducted to test the reliability of the study instrument. The Statistical Package for Social Scientists (SPSS) version 23.0 was used to analyse the data. The results will present the descriptive statistics in the form of graphs, cross tabulations and other figures for the quantitative data that was collected. Chi square test, variance 
analysis (ANOVA), Correlation analysis, and factor analysis are the examples of inferential statistics which were used to interpret the data in this study.

\section{Data Findings}

Table 1.0 below reflects the Cronbach's alpha score for all the items that constituted the questionnaire.

Table 1.0. Cronbach's alpha score

N of Items Cronbach's Alpha

\begin{tabular}{lll}
\hline Effectiveness of traditional media in promoting tourism in Kwazulu-Natal & 8 & 0.902 \\
Effectiveness of online media in promoting tourism in Kwazulu-Natal & 9 & 0.924
\end{tabular}

The reliability scores exceed the recommended Cronbach's alpha value of 0.7. This indicates a degree of acceptable, consistent scoring for the constructs of the study. KMO test was done and the requirement is that Kaiser-Meyer-Olkin Measure of Sampling Adequacy should be greater than 0.50 and Bartlett's Test of Sphericity less than 0.05. In all instances, the conditions are satisfied which allows for the factor analysis procedure. All of the conditions are satisfied for factor analysis as shown in Table 1.1. That is, the Kaiser-Meyer-Olkin Measure of Sampling Adequacy value should be greater than 0.500 and the Bartlett's Test of Sphericity sig. value should be less than 0.05 .

Table 1.1 KMO and Bartlett's Test

\begin{tabular}{lcccc}
\hline & Kaiser-Meyer-Olkin Measure of & \multicolumn{2}{c}{ Bartlett's Test of } \\
& Sampling Adequacy & Sphericity & \\
& & Approx. & d & Sig. \\
Chi-Square & f & \\
\hline $\begin{array}{l}\text { Effectiveness of traditional media in promoting } \\
\text { tourism in Kwazulu-Natal }\end{array}$ & 0.880 & 1548.400 & 2 & 0.0 \\
Effectiveness of online media in promoting tourism & & 1800.491 & 3 & 0.0 \\
in Kwazulu-Natal & 0.916 & 6 & 00 \\
\hline
\end{tabular}

Table 1.2. Rotated Component Matrix: Effectiveness of traditional media

Effectiveness of traditional media in promoting tourism in Kwazulu-Natal

Component

\begin{tabular}{l|c|c}
\hline Advertised messages are more favourable when the ad is placed in a traditional medium. & 0.116 & 0.863 \\
\hline I found that traditional media ads are more influential than online sources & 0.210 & 0.757 \\
\hline I was exposed to an advertising message about KZN via a traditional media channel. & 0.532 & 0.628 \\
\hline Traditional media aroused my need for travel to KZN & 0.698 & 0.456 \\
\hline Information/Advertisements on traditional media caught my attention which made me visit KZN & 0.697 & 0.529 \\
\hline The information advertised on traditional media, generated an interest in me to visit KZN & 0.858 & 0.183 \\
\hline As a result of traditional media I had a desire to visit KZN & 0.883 & 0.195 \\
\hline From the information I found on traditional media, I actioned this interest and came to KZN. & 0.880 & 0.169 \\
\hline
\end{tabular}

Extraction Method: Principal Component Analysis.

Rotation Method: Varimax with Kaiser Normalization.

a. Rotation converged in 3 iterations.

The above section (Table 1.2) also loaded along two components. Respondents therefore identified different trends with the questions that focused on the effectiveness of traditional media for the promotion of tourism. The highest level of scoring (0.880 and 0.863) indicate that traditional media is still favourable for tourism information and is still influential in attracting people to a destination. The results contradict with the assertion by Chao et al. (2012: 21) that traditional media has already faded away globally. The results contradict with other others mainly because the contexts in which the studies were conducted are different. Different countries may have different media consumption patterns, given the 
differences in infrastructural developments. The results suggest that traditional media is still useful in the tourism sector and its role needs not be underestimated.

Table 1.3. Component Matrix; Effectiveness on online media

\begin{tabular}{l|c}
\hline Effectiveness of online media in promoting tourism in Kwazulu-Natal & 1 \\
\hline I drew my list of alternative places to visit through online media. & 0.719 \\
\hline Interactions with virtual friends \& marketers influenced my travel behaviour. & 0.694 \\
\hline I felt drawn to KZN as a result of interacting with marketers online. & 0.703 \\
\hline Online media provides more accurate, relevant and up to date information than traditional media & 0.722 \\
\hline I became aware of certain tourist attractions in KZN through online media. & 0.816 \\
\hline Information/Advertisements on online media caught my attention which made me visit KZN & 0.867 \\
\hline The information advertised on online media generated an interest in me to visit KZN & 0.838 \\
\hline The information from online media aroused a desire in me to visit KZN & 0.855 \\
\hline From the information I found on online media, I actioned this interest and came to KZN. & 0.864 \\
\hline
\end{tabular}

\section{Extraction Method: Principal Component Analysis.}

a 1 components extracted.

Table 1.3 show the statement that constituted this section, "Effectiveness of online media in promoting tourism in KwaZulu-Natal" loaded perfectly along a single component. This implies that the statements that constituted this section perfectly measured what they were set out to measure. It also implies that the respondents understood the meanings and intentions of this set of questions and had similar perceptions towards these questions. The highest levels of scoring $(0.867,0.864,0855,0.838$ and 0.816$)$ indicate that online media is very influential in catching attention of the tourists, generating an interest to visit destinations, arousing a desire to travel, and leading them to take action of travelling to that destination.

\subsection{Use of Traditional Media and Online Media}

This section deals with the use of traditional media and online media by the tourists. The figure (1.0) below summarises the scoring patterns for the statements:

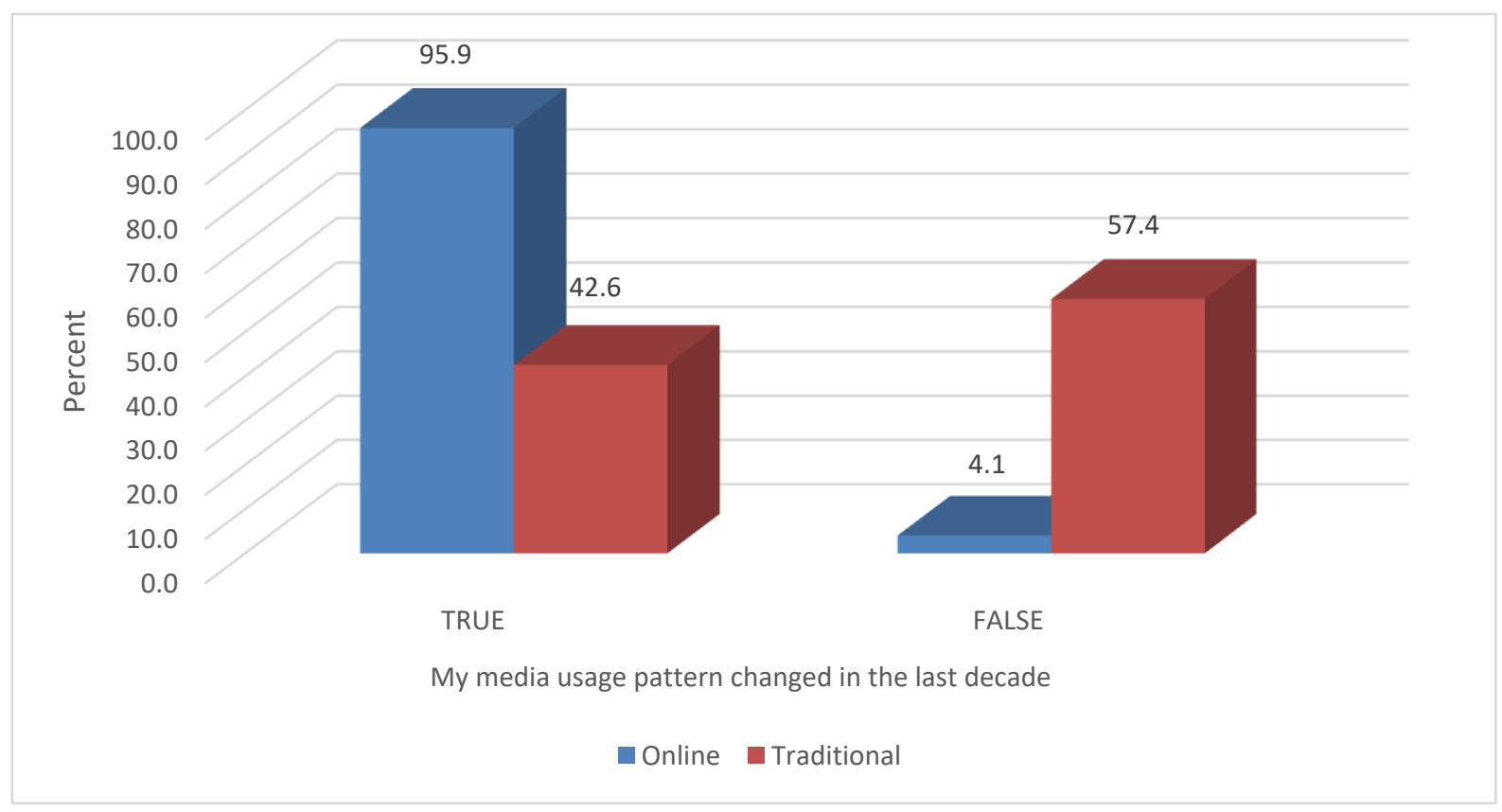

Figure 1.0. Media usage pattern of tourist 
A large number of respondents who were online users $(95.9 \%)$ indicated that there had been a major change in their media usage patterns. Approximately $43 \%$ of the traditional media users also indicated that there had been changes to their media usage patterns. Findings revealed that $57.4 \%$ of tradtional media users did not change their media usage pattern in the last decade. This indicates that there are people still inclined to traditional media use. This implies that traditional media is still usefull for the promotion of tourism $(\mathrm{p}<0.001)$. A biggger change was noticed among online media users as they were adopting the new media This affirms Bergemann and Bonatti's (2011: 417) assertion that online media is increasingly becoming an important medium. The figure (1.1) below indicates the frequeincies of use of the different media.

Table 1.4. Media use frequencies

\begin{tabular}{lccc}
\hline & Online & Traditional & Chi square p-value \\
\hline Television & 63.2 & 36.8 & 0.009 \\
Print & 54.6 & 45.4 & 0.317 \\
Radio & 43.1 & 56.9 & 0.162 \\
Social media & 70.9 & 29.1 & 0.001 \\
Company websites & 64.9 & 35.1 & 0.001 \\
Search engines & 88.7 & 11.3 & 0.001 \\
\hline
\end{tabular}

The resulst are graphically illustrated in the figure (1.1) below.

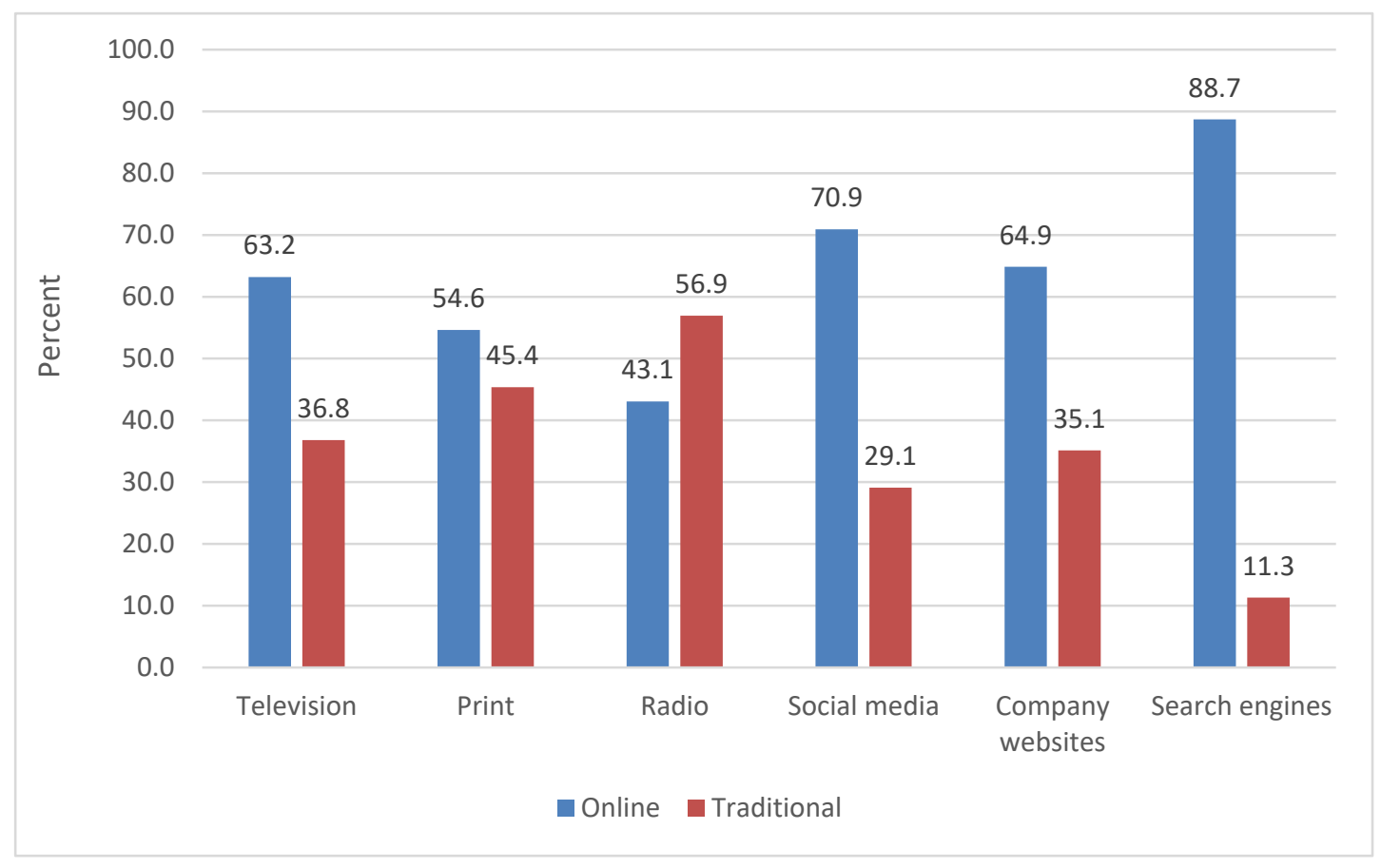

Figure 1.1. Media usage frequencies

There are similar usage patterns between the groups for print and radio ( $p>0.05)$. Print and radio are the mostly used traditional media channels by tourists, they have high values of $45.4 \%$ and 56.9 respectively, higher than other traditional media such as television. Brito and Pratas (2015: 123) state that brochures are a distinctive advertising medium in the tourism industry, while Stuart and Chotia (2012: 109) indicate that radio still remains an important medium in South Africa and it reaches over $88 \%$ of both rural and urban population of 15 years and older in a typical week. These assertions are consistent with these results for radio and print. However, in all other instances, there is significantly higher usage by online media users than traditional media users. The findings revealed that there is a higher usage of online media than traditional media among the tourists. This affirms an assertion by Goyal and Sharma 2013: 44) that there is extensive use of the Internet as a very important source of information

The figure (1.2) below summarises the scoring patterns for the statements: In which media did you come across an advertisement to visit KZN? * Which media do you spent more time using? 
Table 1.5. Media exposure

\begin{tabular}{|c|c|c|c|c|c|}
\hline & & & \multicolumn{2}{|c|}{$\begin{array}{l}\text { Which media do you spent } \\
\text { more time using? }\end{array}$} & \multirow[t]{2}{*}{ Total } \\
\hline & & & Online & Traditional & \\
\hline \multirow{16}{*}{ 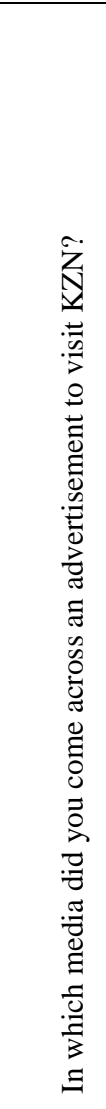 } & \multirow{4}{*}{ Traditional } & Count & 27 & 49 & 76 \\
\hline & & $\begin{array}{l}\% \text { within In which media did you come across an } \\
\text { advertisement to visit KZN? }\end{array}$ & $35.5 \%$ & $64.5 \%$ & $100.0 \%$ \\
\hline & & $\%$ within Which media do you spent more time using? & $13.8 \%$ & $48.5 \%$ & $25.6 \%$ \\
\hline & & $\%$ of Total & $9.1 \%$ & $16.5 \%$ & $25.6 \%$ \\
\hline & \multirow{4}{*}{ Online } & Count & 67 & 3 & 70 \\
\hline & & $\begin{array}{l}\% \text { within In which media did you come across an } \\
\text { advertisement to visit KZN? }\end{array}$ & $95.7 \%$ & $4.3 \%$ & $100.0 \%$ \\
\hline & & $\%$ within Which media do you spent more time using? & $34.2 \%$ & $3.0 \%$ & $23.6 \%$ \\
\hline & & $\%$ of Total & $22.6 \%$ & $1.0 \%$ & $23.6 \%$ \\
\hline & \multirow{4}{*}{ Both } & Count & 78 & 27 & 105 \\
\hline & & $\begin{array}{l}\% \text { within In which media did you come across an } \\
\text { advertisement to visit KZN? }\end{array}$ & $74.3 \%$ & $25.7 \%$ & $100.0 \%$ \\
\hline & & $\%$ within Which media do you spent more time using? & $39.8 \%$ & $26.7 \%$ & $35.4 \%$ \\
\hline & & $\%$ of Total & $26.3 \%$ & $9.1 \%$ & $35.4 \%$ \\
\hline & \multirow{4}{*}{ None } & Count & 24 & 22 & 46 \\
\hline & & $\begin{array}{l}\% \text { within In which media did you come across an } \\
\text { advertisement to visit KZN? }\end{array}$ & $52.2 \%$ & $47.8 \%$ & $100.0 \%$ \\
\hline & & $\%$ within Which media do you spent more time using? & $12.2 \%$ & $21.8 \%$ & $15.5 \%$ \\
\hline & & $\%$ of Total & $8.1 \%$ & $7.4 \%$ & $15.5 \%$ \\
\hline \multirow{4}{*}{ Total } & & Count & 196 & 101 & 297 \\
\hline & & $\begin{array}{l}\% \text { within In which media did you comes across an } \\
\text { advertisement to visit KZN? }\end{array}$ & $66.0 \%$ & $34.0 \%$ & $100.0 \%$ \\
\hline & & $\%$ within Which media do you spent more time using? & $100.0 \%$ & $100.0 \%$ & $100.0 \%$ \\
\hline & & $\%$ of Total & $66.0 \%$ & $34.0 \%$ & $100.0 \%$ \\
\hline
\end{tabular}

The Fisher's p-value indicates that there is a significant difference in the patterns between the two groups (p<0.001). Respondents indicated that they spend more time (two thirds) using online media (66.0\%) than tarditional media (34.0\%). This affirms an asserion by Ling and Yue (2015: 593) that online media has a displacement effect on traditional media. More people 35.4\% indicated that they came across an advertisement to visit KZN through both traditional media and online media. The findings associate with Huang (2012: 9525) claim that traditional media and online media are complementary. Furthermore $25.6 \%$ indicated that they came across an advertisement through traditional media only and $23.6 \%$ through online media only. The results reveal that the appropriation is not complete; therefore, media displacement rather than media replacement has occurred. The findings associate with Okazaki and Romero's (2010: 101) assertion that two media can consequently coexist with some degree of displacement rather than a complete replacement. Furthermore, $15.5 \%$ indicated that they were never exposed to any advertising and this concurs with an assertion by Marrison (2013: 326) who strongly cautions against using a destination's total number of tourists as a measure of effectiveness as it is very unlikely that destination marketing has generated each and every visitor to its destination.

The Table (1.6) below shows the sccoring pattern for the statements:

From which media did you request for information to make arrangements for your trip * Which media do you spent more time using? 
Table 1.6. Media used to request informationfor the trip

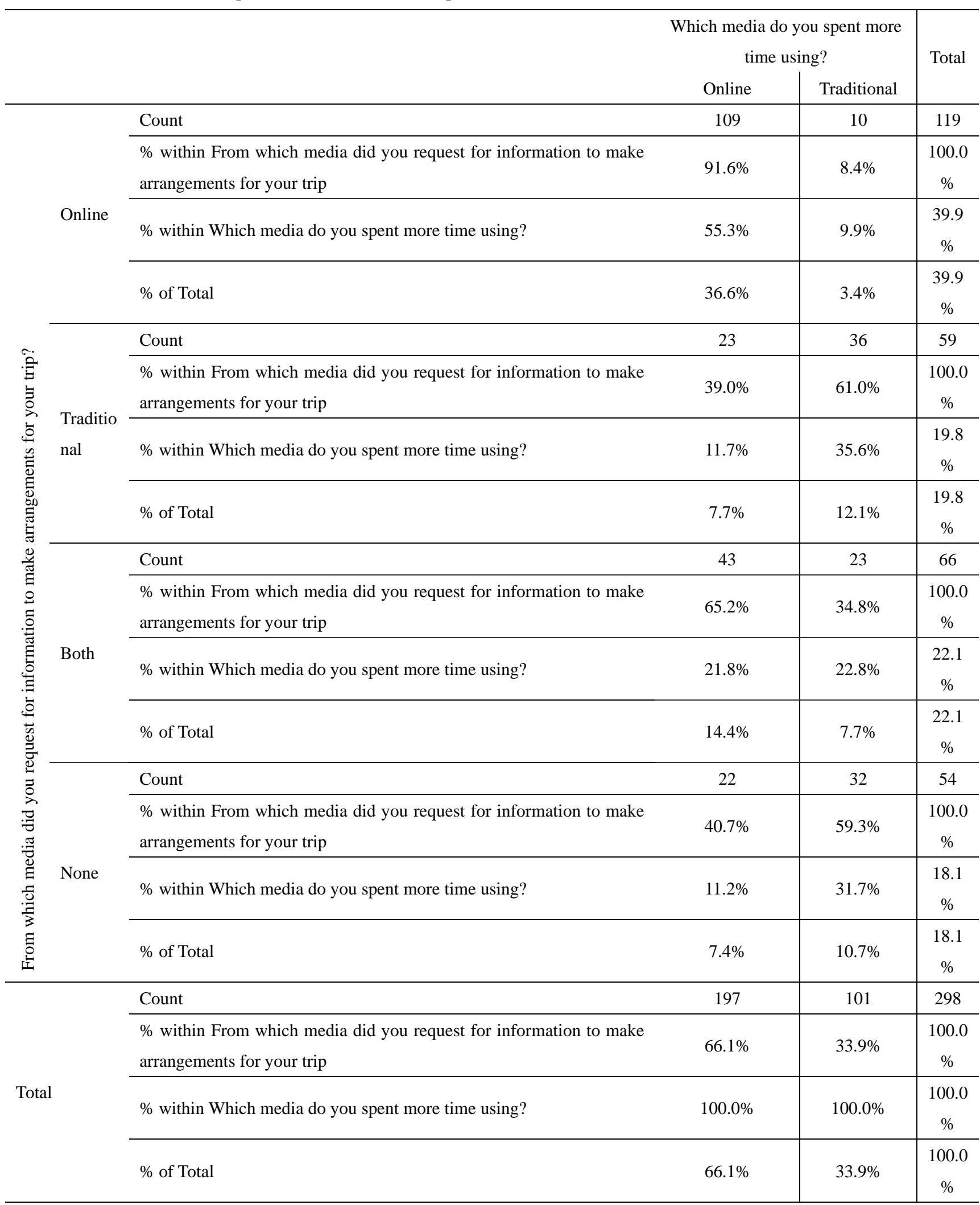

The Fisher's p-value indicates that there is a significant difference in the patterns between the two groups (p < 0.001 ). The majority of the respondents $(39.9 \%$ indicated that they requested for information for their trip through online media, followed by $22.1 \%$ who mentioned that they used both traditional media and online media. Traditional media only was $19.8 \%$ followed by $18.1 \%$ of the respondents who mentioned that they never used any media to request for travel information. The findings correlate with Okazaki and Romero (2010: 101) assertion that individuals interested in 
information procurement in a specific content area will optimise their retrieval of information on that particular content area by exposing themselves to a multitude of media outlets.

The following Table (1.7) shows the results for the statements: I made reservations online * Which media do you spent more time using?

Table 1.7. Media used to make reservations

\begin{tabular}{|c|c|c|c|c|c|}
\hline & & & \multicolumn{2}{|c|}{$\begin{array}{l}\text { Which media do you spent more time } \\
\text { using? }\end{array}$} & \multirow[t]{2}{*}{ Total } \\
\hline & & & Online & Traditional & \\
\hline \multirow{8}{*}{$\begin{array}{l}\text { I made reservations } \\
\text { online }\end{array}$} & \multirow{4}{*}{$\begin{array}{l}\mathrm{Ye} \\
\mathrm{s}\end{array}$} & Count & 107 & 26 & 133 \\
\hline & & $\%$ within I made reservations online & $80.5 \%$ & $19.5 \%$ & $\begin{array}{c}100.0 \\
\%\end{array}$ \\
\hline & & $\begin{array}{l}\% \text { within Which media do you spent more time } \\
\text { using? }\end{array}$ & $54.3 \%$ & $25.7 \%$ & $44.6 \%$ \\
\hline & & $\%$ of Total & $35.9 \%$ & $8.7 \%$ & $44.6 \%$ \\
\hline & \multirow{4}{*}{ No } & Count & 90 & 75 & 165 \\
\hline & & $\%$ within I made reservations online & $54.5 \%$ & $45.5 \%$ & $\begin{array}{c}100.0 \\
\%\end{array}$ \\
\hline & & $\begin{array}{l}\% \text { within Which media do you spent more time } \\
\text { using? }\end{array}$ & $45.7 \%$ & $74.3 \%$ & $55.4 \%$ \\
\hline & & $\%$ of Total & $30.2 \%$ & $25.2 \%$ & $55.4 \%$ \\
\hline \multirow{4}{*}{ Total } & & Count & 197 & 101 & 298 \\
\hline & & $\%$ within I made reservations online & $66.1 \%$ & $33.9 \%$ & $\begin{array}{c}100.0 \\
\%\end{array}$ \\
\hline & & $\begin{array}{l}\% \text { within Which media do you spent more time } \\
\text { using? }\end{array}$ & $100.0 \%$ & $100.0 \%$ & $\begin{array}{c}100.0 \\
\%\end{array}$ \\
\hline & & $\%$ of Total & $66.1 \%$ & $33.9 \%$ & $\begin{array}{c}100.0 \\
\%\end{array}$ \\
\hline
\end{tabular}

More of the online users used online media $(\mathrm{p}<0.001)$. Almost half online media users $(54.3 \%)$ indicated that they made reservations for their trips online. Some of traditional media users $(25.7 \%)$ indicated that they also made reservations online. The results suggest that most of the tourists are not strictly digital or strictly inclined to traditional media.

\subsection{Effectiveness of Traditional Media}

The purpose of the study was to determine the effectiveness of traditional media for the promotion of tourism in this digital age. Table 1.8 and Figure 1.2 below illustrate the scoring pattern of the results obtained.

The Table (1.8) refelects the mean scores for the statements that constituted section $\mathrm{D}$. The means were tested between the two groups, with $\mathrm{p}<0.05$ considered as significant. To determine whether the scoring patterns between the groups were similar, a Mann Whitney test was done. The null hypothesis claims that there is no difference in the central measure. The highlighted sig. values (p-values) are less than 0.05 (the level of significance), it implies that there were differences between the groups for some of half of these statements.

\subsection{The Effectiveness of Online Media}

The other aim of the study was to examine the effectiveness of online media for the promotion of tourism. Table 1.9 and Figure 1.3 illustrate the scoring pattern of the results obtained. 
Table 1.9. Effectiveness of online media

\begin{tabular}{|c|c|c|c|c|c|c|c|}
\hline & & $\begin{array}{l}\text { Onlin } \\
\mathrm{e}\end{array}$ & $\begin{array}{l}\text { Tradition } \\
\text { al }\end{array}$ & $\begin{array}{l}\text { Mann-Whitn } \\
\text { ey U }\end{array}$ & $\begin{array}{l}\text { Wilcox } \\
\text { on } \mathrm{W}\end{array}$ & $\mathrm{Z}$ & $\begin{array}{l}\text { Asym } \\
\text { p. Sig. } \\
\text { (2-tail } \\
\text { e) }\end{array}$ \\
\hline $\begin{array}{l}\text { I drew my list of alternative places to } \\
\text { visit through online media. }\end{array}$ & D4.1 & 3.55 & 3.20 & 7540.50 & $\begin{array}{l}12691.5 \\
0\end{array}$ & $\begin{array}{l}-3.57 \\
9\end{array}$ & 0.000 \\
\hline $\begin{array}{l}\text { Interactions with virtual friends \& } \\
\text { marketers influenced my travel } \\
\text { behaviour. }\end{array}$ & $\mathrm{D} 4.2$ & 3.38 & 3.17 & 8664.00 & $\begin{array}{l}13815.0 \\
0\end{array}$ & $\begin{array}{l}-1.90 \\
7\end{array}$ & 0.057 \\
\hline $\begin{array}{l}\text { I felt drawn to KZN as a result of } \\
\text { interacting with marketers online. }\end{array}$ & D4.3 & 3.06 & 3.02 & 9710.50 & $\begin{array}{l}14861.5 \\
0\end{array}$ & $\begin{array}{l}-0.35 \\
3\end{array}$ & 0.724 \\
\hline $\begin{array}{l}\text { Online media provides more accurate, } \\
\text { relevant and up to date information } \\
\text { than traditional media }\end{array}$ & D4.4 & 3.26 & 2.90 & 8347.00 & $\begin{array}{l}13498.0 \\
0\end{array}$ & $\begin{array}{l}-2.34 \\
0\end{array}$ & 0.019 \\
\hline $\begin{array}{l}\text { I became aware of certain tourist } \\
\text { attractions in KZN through online } \\
\text { media. }\end{array}$ & D4.5 & 3.53 & 3.04 & 7314.00 & $\begin{array}{l}12465.0 \\
0\end{array}$ & $\begin{array}{l}-3.86 \\
1\end{array}$ & 0.000 \\
\hline $\begin{array}{l}\text { Information/Advertisements on online } \\
\text { media caught my attention which made } \\
\text { me visit KZN }\end{array}$ & D4.6 & 3.37 & 2.78 & 6958.00 & $\begin{array}{l}12109.0 \\
0\end{array}$ & $\begin{array}{l}-4.37 \\
9\end{array}$ & 0.000 \\
\hline $\begin{array}{l}\text { The information advertised on online } \\
\text { media generated an interest in me to } \\
\text { visit KZN }\end{array}$ & D4.7 & 3.23 & 2.77 & 7594.00 & $\begin{array}{l}12745.0 \\
0\end{array}$ & $\begin{array}{l}-3.44 \\
6\end{array}$ & 0.001 \\
\hline $\begin{array}{l}\text { The information from online media } \\
\text { aroused a desire in me to visit KZN }\end{array}$ & D4.8 & 3.12 & 2.75 & 8108.00 & $\begin{array}{l}13259.0 \\
0\end{array}$ & $\begin{array}{l}-2.73 \\
1\end{array}$ & 0.006 \\
\hline $\begin{array}{l}\text { From the information I found on online } \\
\text { media, I actioned this interest and came } \\
\text { to KZN. }\end{array}$ & D4.9 & 3.29 & 2.64 & 6928.00 & $\begin{array}{l}12079.0 \\
0\end{array}$ & $\begin{array}{l}-4.40 \\
7\end{array}$ & 0.000 \\
\hline
\end{tabular}

The Table (1.9) refelects the mean scores for the statements that constituted the section. The means were tested between the two groups, with $\mathrm{p}<0.05$ considered as significant. To determine whether the scoring patterns between the groups were similar, a Mann Whitney test was done. The null hypothesis claims that there is no difference in the central measure. The results are shown in Table 1.9 above. The highlighted sig. values (p-values) are less than 0.05 (the level of significance), it implies that there were differences between the groups for these statements.

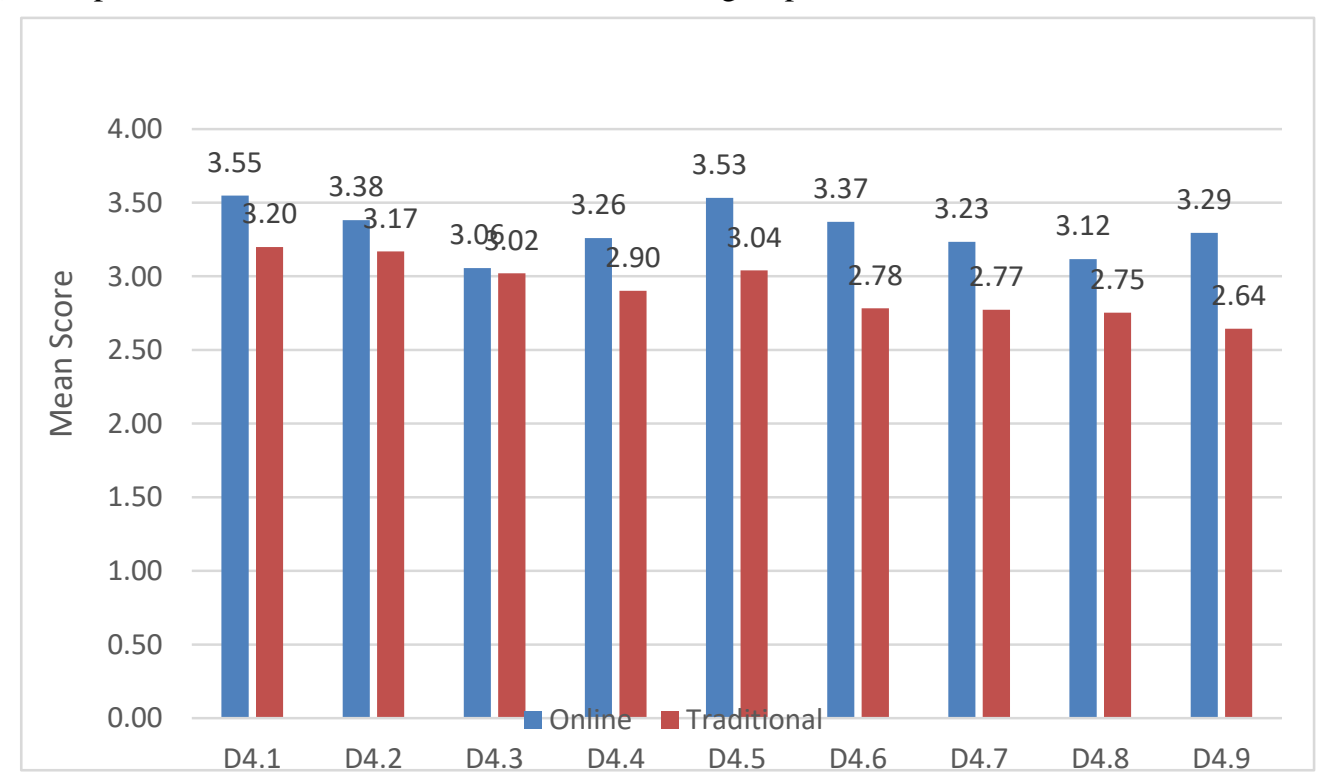

Figure 1.3. Effectiveness of online media

The general pattern observed is that online media has higher mean scores than traditional media for all for all variables under investigation in this section. Many respondents (mean score 3.55) acknowledged that they drew their lists of 
alternative places to visit through online media. Furthermore, most respondents (mean score 3.53) indicated that they became aware of certain tourist attractions in KZN through online media. The results correlate with an assertion by Chung, Nam and Stefanone (2012: 171) that online media has global market reach and permanent exposure. The majority of the respondents (mean score 3.38) also mentioned that interactions with virtual friends influenced their travel behaviour. The findings support an assertion by Hudson and Thal (2013: 158) that customer interaction through social media is now playing a pivotal role in decision making. Some respondents (mean score 3.29) indicated that from the information they found from online sources, an interest to visit KZN was generated and they actioned that interest and came to KZN. The results associate with Strauss and Frost's (2014: 68) assertion that social media is used in the tourism business industry to push sales by attracting more tourists to South African destinations. The results suggest that as with traditional media, online media is also effective for the promotion of tourism but with more efficiency than traditional media.

\section{Conclusion and Recommendations}

The results collected from this study underline the significant use of both traditional media and online media for the promotion of tourism in Kwazulu-Natal. The results revealed that though there are people who are inclined to traditional media and others have indeed turned to online media. The findings reveal that traditional media is still effective and more credible for toursim information in this digital age. The results further reveal that the appropriation effect of online media to traditional media is not complete; therefore, media displacement rather than media replacement has occurred. Practitioners and customers need to come to terms with traditional media and online media coexistence rather than speculating the demise of one media (traditional media) whilst overestimating the effectiveness of another media (online media). Tourism is indeed a unique sector where traditional media is still yielding good results whilst working alongside online media. The results suggest that traditional media and online media are complementary. However, online media alone cannot be enough to supply that much needed information. Television, radio, brochures, magazines, billboards and newspapers are still very useful in reaching the other segments of the market. In fact at this stage, online media should be used to supplement the promotional efforts executed in the traditional media as the primary media in the tourism sector of KZN. In a conclusion the study data showed that tourists use both traditional media and online media for their tourism information needs. Both traditional media and online media were found to be useful for the promotion of tourism in this digital era and the pattern indicated a higher usage of online media than traditional media by tourists. It was revealed that traditional media is not dead; it is still effective for the promotion of tourism, especially in the domestic market. To discredit traditional media in favour of online media is short-sighted, mere excitement, and a clear way of running away from the reality that traditional media is widely used for the promotion of tourism and is still yielding a positive response.

The following recommendations can assist tourism marketers to effectively promote their sector by making sound and informed media decisions. It has been noticed that advertising in this digital age is not only limited to the Internet. Creative marketers can use any media that can effectively reach the target audience such as TV, radio, magazines, brochures, billboards, posters, and newspapers. Tourism marketers should, by any means, underestimate the role of traditional media in the promotion of their destinations. Traditional media is still effective for the promotion of tourism and it ranks high in terms of credibility. The domestic market, which also constitutes the bulk of the tourists visiting KZN, still relies heavily on traditional media than online media. As a result, marketers should continue to use traditional media to promote domestic tourism because of its sheer volume and its benefits for sustainability and seasonality. Marketers need to increase their presence online without neglecting the use of traditional media. Though traditional media is said to be expensive, it still yields a positive response. The study recommends tourism marketers and authorities to improve their uptake of the Internet and to be more innovative online so as to cater for the needs of the customers whose preference is online media. Marketing initiatives should be improved in order to meet the global trends. One of the recent trends around the world is the development of tourism applications to be used on smart phones, which provide an array of tourism information. Examples of other global trends include: virtual tour guides, alternate reality gaming, geo-caching, and participant route mapping. These initiatives have a high potential of engaging the target market and improves the competitiveness of the destination. As a result, innovation towards the development of these applications is a necessity in order to efficiently serve the needs of travellers. All media, traditional or none-traditional should be used for the promotion of tourism. There is no need to rely on one media to do it all. Though online media has a wider reach in the global environment, it does not reach the whole world, hence the need to integrate with traditional media. The world is communication-saturated so it takes many touch points to be noticed in the market. Where traditional media lacks, online media must be there to make up the difference and enhance the tourist's experience.

\section{Limitations}

This study was limited to the tourism sector of Kwazulu-Natal. This compromised the generalisability of the findings, 
but this could be strengthened if the study was to be replicated in other tourism destinations similar to KZN and with a larger sample. In addition, the media landscape is ever-changing so what has been found to be true today cannot be equally true in the near future. By conducting surveys among the actual tourist, the study also failed to incorporate the cognitive/attitudinal dimensions that do not bring about an immediate visit but rather a long term behavioural change. The performance of advertising media in tourism marketing is not limited to actual visits to a destination but is extended to a number of behavioural changes and psychological effects such as destination image formation. Those psychological effects may bring about a visit in the long run. It's a drawback that the study was based on actual visits and potential visitors to KZN were not incorporated.

Areas of Further Research

Given the limitations of this study, the researcher has identified opportunities for further research. Research should be conducted incorporating potential visitors to a destination as well since the effects of an ad are not only manifested in actual visits but may cause long term behavioural changes or psychological effects that will influence a visit in the longer term. More research should be conducted to explore the role played by other elements of the promotion mix such as personal selling, public relations, and sales promotion. Their performance in terms of promoting tourism is not well covered in the literature.

\section{References}

Bergemann, D., \& Bonatti, A. (2011). Targeting in advertising markets: implications for offline versus online media. The RAND Journal of Economics, 42(3), 417-443. https://doi.org/10.1111/j.1756-2171.2011.00143.x

Blaga, R. L. (2013). Establishing the communication mix of tourism organisations by the objectives communication, through gradually knowledge of the customer profile. Economic Series, 23(4), 29-40.

Brito, P. Q., \& Pratas, J. (2015). Tourism brochures: Linking message strategies, tactics and brand destination attributes. Tourism Management, 48, 123-138. https://doi.org/10.1016/j.tourman.2014.10.013

Bruhn, M., Schoenmeuller, V., \& Schafer, D. B. (2012). Are social media replacing traditional media in terms of brand equity creation? Management Research Review (online), 35(9), 770-790. Available: www.emeraldinsight.com/2040-8269.htm (Accessed 15 April 2016). https://doi.org/10.1108/01409171211255948

Chao, C., Corus, C., \& Li, T. (2012). Balancing traditional media and online advertising strategy. International Journal of Business, Marketing, and Decision Sciences (online), 5(1), 12-24. Available: www: http://content.ebscohost.com.dutlib.dut.ac.za (Accessed 15 April 2016).

Chipp, K. F., \& Chakravorty, D. (2016). Producer push to consumer pull: who curates new media content? Developing strategies for new media environments. Journal of Product \& Brand Management, 25(4), 373-386. https://doi.org/10.1108/JPBM-06-2015-0918

Chung, C. J., Nam, Y., \& Stefanone, M. A. (2012). Exploring Online News Credibility: The Relative Influence of Traditional and Technological Factors. Journal of Computer-Mediated Communication, 17(2), 171-186. https://doi.org/10.1111/j.1083-6101.2011.01565.x

Dahlen, M., \& Edenius, M. (2007). When advertising is advertising? Comparing responses to non-traditional and traditional advertising media. Journal of current issues and research in advertising (Online), 29(1), 34-42. Available: $\quad$ http://dut.summon.serialssolutions $\quad$ (Accessed $17 \quad 17$ April 2016). https://doi.org/10.1080/10641734.2007.10505206

Debasish, S. S., \& Muralidhar, M. (2013). Print Advertising: Consumer Behaviour. Journal of Indian Management, Quarterly: 78-89.

Durban Tourism, (2013). Taking Durban to the world. Visitor marketing strategy 2013-2020. Durban: Ethekwini Municipality.

Fyall, A., Fletcher, J., \& Spyriadis, T. (2009). Diversity, Devolutional disorder, Management of tourism destinations. London: Routledge.

Goyal, N., \& Sharma, S. K. (2013). The use of government tourism websites as a tool for promoting tourism. Journal of Hospitality and tourism system, 6(2), 44-52.

Hanekom, D. (2015). Geared to listen: South African Tourism Minister welcomes the world to Indaba 2015. Indaba Daily News (online), May 9: 1. Available: http://www.indaba-southafrica.co.za (Accessed 20 April 2016).

Howison, S., Finger, G., \& Hauschka, D. (2014). Insights into Web presence, online marketing, and the use of social media by tourism operators in Dudedin, New Zealand. An International Journal of Tourism and Hospitality Research (online), 26(2), 269-283. Available: http://www.tandfonline.com/loi/rana20 (Accessed 01 October 2016). 
https://doi.org/10.1080/13032917.2014.940357

Huang, Y. K. (2012). Marketing budget allocation and marketing benefits of traditional media, online advertising, and electronic word of mouth. African journal of business management (online), 3933): 9524-9532. Available: http://www.academicjournals.org/AJBM (Accessed 17 April 2016).

Hudson, S., \& Thal, K. (2013). The impact of social media on the consumer decision process: Implications for tourism marketing. Journal of Travel and Tourism Marketing (online), 30(2), 156-160. Available: http://www.tandfonline.com/loi/wttm20 (Accessed $01 \quad$ October https://doi.org/10.1080/10548408.2013.751276

Ling, J., \& Yue, Z. (2015). Research on the displacement effect of the Internet on the traditional media. International journal of social science and humanity (online), 5(7), 589-596. Available: 10.7763/IJSSH.2015.V5.523. (Accessed 01 March 2017). https://doi.org/10.7763/IJSSH.2015.V5.523

Loda, M. D. (2014). Suggesting a more effective way to use the promotion mix in services. Services Marketing Quarterly (online), quarterly: 304-320. Available: http://www.tandfonline.com/loi/wsmq20 (Accessed 04 June 2016). https://doi.org/10.1080/15332969.2014.946875

Marrison, A. M. (2013). Marketing and Managing tourism destinations. New York: Routledge. https://doi.org/10.4324/9780203081976

Nzima, T. (2015). South Africa ready to host African Tourism ministers ahead of Indaba. News24. (online), May 4: 5. Available: http://traveller24.news24.com (Accessed 20 May 2016).

Okazaki, S., \& Romero, J. (2010). Online media rivalry: A latent class model for mobile and PC internet users. Online Information Review (online), 34(1), 98-114. Available: http://dx.doi.org/10.1108/14684521011024146 (Accessed 11 January 2017). https://doi.org/10.1108/14684521011024146

Pomering, A., Noble, G., \& Johnson, L. W. (2011). Conceptualising a contemporary marketing mix for sustainable tourism. Journal of Sustainable Tourism (online), 19(8), 953-969. Available: http://dx.doi.org/10.1080/09669582.2011.584625 (Accessed 02 June 2016). https://doi.org/10.1080/09669582.2011.584625

Seymour, J., Stolk, M., \& Kohler, K. (2009). Tourism Kwazulu-Natal: A developer's guide to investment in tourism projects in Kwazulu-Natal (Online), Available: http://www.msunduzi.gov.za/site/home (Accessed 5 October 2016).

Statistics South Africa. (2016). Tourism. (online). Available www.statssa.gov.za/publications/Reports (Accessed, 06 May 2016).

Strategic Direction. (2016). A new democracy for new media: challenges to traditional media and adapting to modern consumers", Strategic Direction (online), 32(11), 7-9. Available: https://doi.org/10.1108/SD-08-2016-0123 (Accessed 20 October 2017). https://doi.org/10.1108/SD-08-2016-0123

Stuart, C., \& Chotia, A. (2012). South African entertainment and media outlook: Radio (online).Available: www.pwc.co.za/outlook (Accessed 01 April 2017).

Sturgis, S. (2012). Are traditional media dead. Can journalism survive in the digital world. New York: The International Debate Education Associations.

Tourism Kwazulu-Natal. (2014). Statistics of our tourism sector 2014 (online), Available: http://www.zulu.org.za/files/images/files/140919080_TKZN\%20Stats\%20brochure_Lo.pdf (Accessed 02 October 2016).

Van, C. N., \& Tu, L. T. (2016). Impact of e-commerce website on small tourism enterprises in quang binh, Vietnam, Journal of Asian Business Strategy, 6(10), 221. https://doi.org/10.18488/journal.1006/2016.6.10/1006.10.221.225

Zentner, A. (2012). Internet adoption and advertising expenditures on traditional media: An empirical analysis using a panel of countries. Journal of economic and management strategy (online), 21(4), 913-926. Available:

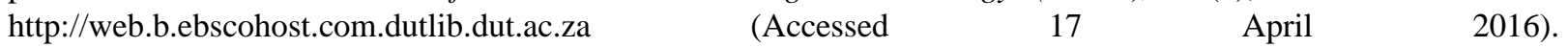
https://doi.org/10.1111/j.1530-9134.2012.00355.x

\section{Copyrights}

Copyright for this article is retained by the author(s), with first publication rights granted to the journal.

This is an open-access article distributed under the terms and conditions of the Creative Commons Attribution license which permits unrestricted use, distribution, and reproduction in any medium, provided the original work is properly cited. 